St udi a P i los o phic a

Wratis lavien s i a

vol. XV, fasc. $1(2020)$

https://doi.org/10.19195/1895-8001.15.1.4

PAWEE SIKORA

ORCID: 0000-0001-7960-0786

Uniwersytet Marii Curie-Skłodowskiej w Lublinie

\title{
Pojęciowa treść percepcji a realizm epistemologiczny. Zarys problemu
}

\section{Conceptual Content of Perception and Epistemological Realism. An Outline of the Problem}

\begin{abstract}
The author claims that the conceptual content of perception can serve as an argument in favour of epistemological realism. He argues on behalf of the main theses of conceptualism in philosophy of perception, and explores the relational aspects of perceptual objects which make up the general conditions determining their reality. The relational aspects are as follows: the unity of quantitative and qualitative contents, their concomitance and inherence property in relation to an object. These general aspects are essential for epistemological realism and establish the correlates of the conceptual identification of objects of perception.
\end{abstract}

Keywords: conceptual content of perception, epistemological realism, empiricism, object of perception, relations

\section{Wprowadzenie}

Zmysłowe postrzeganie jest specyficznym problemem w filozofii, skupia się bowiem na momencie kontaktu podmiotu ze sfera przedmiotową. Niemal wszystkie teorie percepcji — niezależnie od ogromnych różnic — zakładają, iż sfera podmiotowego ujmowania jest epistemicznie odmienna od tego, co uznaje się za treść postrzeżenia. Obecność tej różnicy jest fundamentem, na którym tworzy się modele, wyjaśniające jak się mają wewnętrzne doznania podmiotu do stanu świata. Wydaje się, iż po Kartezjuszu wciąż mamy kłopot z pomostem między umysłem a rzeczywistością, a rozstrzygnięcia w filozofii percepcji mogą być szansą na rozwiązanie 
tego problemu, dzięki czemu można także ustalić pewien meta-epistemiczny status całości doświadczenia.

Jeśli przez percepcję rozumieć doświadczenie zmysłowe o charakterze świadomego stanu lub czynności umysłu, który polega na przedstawieniu lub ujęciu jakiejś empirycznej treści, to dla przejrzystości niniejszego wywodu i z perspektywy myślenia o strukturze percepcji odróżniam doznawanie owej treści od postrzegania, jako całości naszych stanów percepcyjnych, w których można z kolei wyodrębnić zarówno owo doznanie, jak i pojęciowy komponent. Przez treść percepcji uznaję konkretną, ilościowo-jakościową zawartość doznania (na przykład czerwone, słodkie, długie, twarde, gładkie, małe) wraz z licznymi powiązaniami tychże treści, które przedstawiają zewnętrzny stan rzeczy. Określenie „pojęciowa treść percepcji” odnosi się z kolei nie tyle do skonstruowanego lub gotowego pojęcia czy definicji, jako obiektu w umyśle, będącego reprezentacją pewnych ogólnych własności i nakładanego na treści zmysłowe. Przez pojęciową treść percepcji rozumie się zwykle przejaw aktywności wnioskowania czy wydawania sądów obecnych w procesie postrzegania — w ten sposób w percepcji ujawnia się treść reprezentacyjna ${ }^{1}$. Uważam jednak, iż pojęciowa treść nie jest jedynie przejawem owej podmiotowej aktywności inferencyjnej i propozycjonalnej, lecz jest także zdolnością ujmowania i rozpoznawania ogólnych określeń zawartych już w treści postrzeżenia. W tym sensie percepcja nie jest pojedynczym, wyizolowanym doznawaniem jakiejś poszczególnej, zmysłowej treści, lecz odnosi się do treści już upojęciowionej: jest ona zarówno zmysłowa, ale także już ustrukturalizowana przez podmiotową aktywność wiedzotwórczą. Zwolennicy stanowiska conceptual content wskazują, iż nie ma różnicy między stanem „doznaję x" a konstatacja ,wiem, że doznaję x”, zaś wiedza o tym doznaniu nie dotyczy jedynie zdolności myślenia o fakcie doznawania jako czynności odrębnej, drugorzędnej czy występującej rzekomo po uprzednim doznaniu, lecz jako wyraz aktywności propozycjonalnej, a więc pojęciowo wyrażonej wiedzy zmysłowej, wyeksplikowanej w sądzie.

Przy tak zarysowanym polu problemowym można byłoby uznać, iż spory o obecność i funkcjonowanie pojęciowej treści należą do takiego obszaru epistemologii, która zajmuje się głównie procesami wiedzotwórczymi, występującymi niejako pomiędzy postrzeżeniem a myśleniem. W moim przekonaniu — i taka jest zasadnicza teza niniejszego artykułu — pojęciowa treść ma charakter inferencyjny i propozycjonalny, o ile poprzedza ją empiryczna aktywność podmiotu, który już na poziomie percepcji rozpoznaje ogólne komponenty czy też pewne niezmienniki doświadczenia w samym przedmiocie percepcji. Dzięki temu problem pojęciowej treści percepcji odnosi się w równym stopniu do kwestii teoriopoznawczego realizmu, nie tylko ze względu na charakterystykę postrzegania jako nakierowania się na przedmiot, lecz także ze względu na samą strukturę treści percepcji: pojęciowego komponentu, powiązanego z czysto empiryczną, zmysłową określonością. Przekonanie to bierze się z dość prostej konstatacji, iż teorie percepcji, często odnosząc się do konkretnych przykładów, wskazują na specyfikę kontaktu umysłu z doświadczanymi treściami lub wskazują po prostu na charakter percepcji jako

${ }^{1}$ Por. B. Brewer, Perceptual Experience Has Conceptual Content, [w:] Contemporary Debates in Epistemology, M. Steup, E. Sosa (red.), Malden 2005, s. 217-219. 
pewnej otwartości na świat. Brewer nazywa to perspektywicznym charakterem percepcji — jest ona nasza, ale wiąże nas także ze światem². Można zradykalizować i tę perspektywę, twierdząc, iż niezależnie od tego, co uznajemy za treść doświadczenia zmysłowego percepcja jest stanem wektorowego zwrócenia się w kierunku jakiegoś przedmiotu postrzeżenia. Jeśli zatem chcemy mówić o empirycznej treści zmysłowej, to właśnie dlatego, że jest ona postrzeżeniem jakiejś treści dla podmiotu, musimy uznać jej odmienny od podmiotowego charakter. Ten wstępny warunek formalny struktury doświadczenia, zauważony już przez Reinholda i Fichtego jest niezbędny o tyle, że w innym przypadku percepcja czegoś nieodróżnialnego od samego podmiotu uniemożliwiałaby dostrzeżenie, iż owo coś jest mu dane i jako takie jest inne niż on sam.

Kiedy mowa o pojęciowej treści, to oprócz samych doznań podmiotu uwypukla się jednocześnie istnienie pewnych koniecznych, dodatkowych warunków, których spełnienie umożliwia relację zmysłowego doświadczenia z zewnętrznym przedmiotem $^{3}$. Warunki te są podmiotowe i jednocześnie wiedzotwórcze, a jako takie osadzają się na pojęciowych zdolnościach owego podmiotu. Relacyjność percepcji nie dotyczy więc tylko nakierowania na świat, lecz weredycznie reprezentacyjny charakter percepcji wynika także z zawartej w postrzeżeniu zmysłowej identyfikacji przedmiotu $o$ jako $o \mathrm{w}$ jego ogólnej, relacyjnej strukturze. Strukturę tę rozpoznajemy dzięki pojęciowym zdolnościom już obecnym w postrzeganiu. Innymi słowy, jeśli percepcja przedstawia realny stan świata wokół nas, a treść zawiera coś więcej niż samą zmysłową określoność, to można wyróżnia się dwa momenty relacyjne:

1. poznawczo-przedmiotowy, gdzie percepcja jest otwartością na świat, a treść percepcji jest określana przez nasze zdolności rozpoznawania faktu, że przedmiot $o$ jest taki a taki ${ }^{4}$. Skutkuje to wnioskiem, iż treść percepcji jest pojęciowa ze względu na jej inferencyjny i propozycjonalny charakter;

2. różnicująco-wybiórczy, gdzie percepcja uruchamia nasze zdolności wyodrębniania i ujmowania odmiennych aspektów percypowanych obiektów — sytuacji, rzeczy czy własności ${ }^{5}$. Treść percepcji nie musi być per se uznana za pojęciową, w znaczeniu zawartości inferencyjnej czy propozycjonalnej, ale jej struktura jest z pewnością także ogólna i relacyjna, bo ujmuje nie tylko sam komponent doznaniowy ${ }^{6}$.

Chciałbym jednakże zwrócić uwagę na trzeci moment relacyjny, który ze względu na swoje znaczenie w zagadnieniu realności treści percepcyjnej można nazwać momentem konkretyzacji. Występuje on w trzech aspektach: a) współwystępowania treści, b) ich jedności w ilościowo-jakościowej charakterystyce i c) bycia własnością przedmiotu. W moim przekonaniu odgrywają one istotną rolę wiążącą

2 B. Brewer, Foundations of Perceptual Knowledge, „American Philosophical Quarterly” 34(1), 1997, s. 43.

${ }^{3}$ Por. J. McDowell, Perceptual Experience: Both Relational and Contentful, ,European Journal of Philosophy" 21(1), 2013, s. 145, 147, 150-151; M.D. Conduct, Naïve Realism and Extreme Disjunctivism, „Philosophical Explorations” 13(3), 2010, s. 202.

${ }^{4}$ Por. J. McDowell, Mind and World. With a New Introduction, Cambridge 1996, s. 9.

${ }^{5}$ Por. S. Schellenberg, Perceptual Content and Relations, „Philosophical Studies” 163(1), 2013, s. 49-55.

${ }^{6}$ Por. S. Schellenberg, Perceptual Particularity, „Philosophy and Phenomenological Research” 93(1), 2016, s. 28. 
tezę o pojęciowej treści percepcji z epistemologicznym realizmem i na nich tutaj chciałbym się skupić.

\section{Percepcja a problem realizmu}

Stanowisko epistemologicznego realizmu można sprowadzić do trzech, kluczowych aspektów:

I. realnego, rzeczywistego, prawdziwego istnienia czegoś, co jest przedmiotem poznania;

II. przedmiot ów jest dany obiektywnie;

III. przedmiot ów istnieje jedynie poza sferą podmiotową.

Można zatem przyjąć, iż przedmiotami percepcji są sytuacje, rzeczy i własności rzeczy. Pojawiają się one jako pewne przedstawienia w postaci ilościowo-jakościowych treści zmysłowych, już w pewnym uporządkowaniu (kubek stojący na biurku obok mnie jest biały i owalny). Jeśli zatem teorie percepcji mają być wsparciem dla empirycznego realizmu, to należy przyjacć, iż nie da się uchwycić w postrzeżeniu jakiejś minima sensibilia, pewnej jednostkowej, wyizolowanej danej, posiadającej jedynie jakościową określoność (na przykład białość). W innym wypadku bowiem wracamy do dawnych kłopotów i aporii związanych z przejściem od pojedynczych doznań do realnego stanu świata poza nami. Twierdzę także, iż przedmioty postrzeżenia nie mają charakteru czysto prywatnego — są oczywiście zawsze doznawane przez indywiduum, ale są także dostępne dla innych i w ten sposób ich odbieranie jest także intersubiektywną detekcją, że coś jest takie a takie. Dzięki temu możliwe jest zrozumiałe wyrażanie się o zwykłych sytuacjach (,oto biały kubek”). Poczynione uwagi wynikają z prostej konstatacji, iż skoro teorie percepcji opierają się na przykładach, to konkretna sytuacja, stan rzeczy czy postrzegane własności rzeczy wskazują, iż przedmioty te mają pewną ilościowo-jakościową jedność i nie ujawniają się w postrzeżeniu jako odrębne dane, które potem myślenie „składa” do postaci sytuacji czy rzeczy ${ }^{7}$. Innymi słowy, relacyjna, ilościowo-jakościowa jedność przedmiotu postrzeżenia wskazuje zarówno na jej pojęciowo uchwytywalny charakter, jak i konkretną, realną, zmysłową określoność. W innym wypadku, należałoby powiedzieć, iż percepcja jest z jednej strony ujęciem zmysłowych minimów, lecz ujawniają się one w umyśle (na przykład jako idee, impresje, czy dane) i dopiero wnioskowanie łacczy

\footnotetext{
7 Wywodzący się od Locke'a znany podział na idee proste i złożone oraz na jakości pierwotne i wtórne ma charakter myślowej konstrukcji, potrzebnej do obrony empirycznego fundacjonalizmu i jednocześnie ma podkreślać, iż doświadczenie doświadcza co prawda tylko idei w umyśle, ale dzięki ideom cech pierwotnych ma swoje ugruntowanie w obiektywności. U Locke'a struktura procesu postrzegania wydaje się jednocześnie zachowywać jedność świata doświadczenia, albowiem podział na ilościowe i jakościowe aspekty jest przedmiotem li tylko filozoficznej analizy, bo przecież w momencie postrzeżenia oba rodzaje cech są dane razem. Dla refleksji czym innym są idee cech pierwotnych (obiektywnych), czym innym zaś idee cech wtórnych (subiektywnych), jednak myślenie dokonując tego rozróżnienia nie narusza ich bycia danym, jako współwystępujących, ilościowo-jakościowych całości w postaci percypowanych przedmiotów. O kontrowersjach z podziałem na własności pierwotne i wtórne pisze szerzej: M. Johnston, How to Speak of the Colors, „Philosophical Studies: An International Journal for Philosophy in the Analytic Tradition" 68(3), 1992, s. 221-263.
} 
je z faktycznym stanem świata. Przy takim rozwiązaniu stanowisko empirycznego realizmu nie mogłoby posiłkować się jakąkolwiek teorią percepcji i wciąż wikłałoby się w aporie, wskazane przez Kanta w jego pierwszej Krytyce.

Jeśli przez „przedmiot” rozumieć tutaj coś, co jest korelatem poznania, lub w tym przypadku — szczegółowiej: zmysłowego doświadczenia, to realizm epistemologiczny w odniesieniu do filozofii percepcji dotyczy tego, co: istniejące naprawdę w postrzeganiu, jest dane niezależnie od podmiotu i istniejące na zewnątrz niego. Problem, jaki tutaj się zarysowuje jest następujący: z perspektywy historycznych przykładów w filozofii percepcji kwestia realnego istnienia w zewnętrznej obiektywności odnosi się często nie do ogólnie pojmowanego ,świata poza nami", lecz do podmiotowych stanów zawierających zmysłowe treści (idee, dane) i będących (w niektórych przypadkach) reprezentacjami zupełnie zewnętrznych stanów rzeczy, przedmiotów fizycznych i ich własności. Innymi słowy, percepcja ma umożliwiać kontakt podmiotu z rzeczywistością; kontakt ów (niezależnie czy pośredni, czy bezpośredni) ma dawać pewność, iż to, co dane w percepcji łączy podmiot ze światem. Jednak od czasów Locke'a filozofia percepcji wydaje się „ześlizgiwać” w stronę podmiotu, bo gdy mówi się o postrzeganiu, to dokonuje się redukcji do samego doznawania wrażeń, idei zmysłowych, impresji danych lub treści (traktowanych jako jednostkowe, czysto zmysłowe istotności). Mówi się zatem albo o reakcjach podmiotu, albo o śladach oddziaływania świata na nas, a więc o tym, co pojawia się tylko po stronie podmiotu. Nie ma wtedy pewności, czy na poziomie samej percepcji podmiotowy stan świadomego doznawania jest weredyczną reakcją na to, co realne; nie ma pewności, czy jakikolwiek związek ze światem tu zachodzi. Kłopot, jaki pozostawił nam nowożytny, empiryczny ideizm, dotyczy zatem: na ile percepcja rzeczywiście umożliwia kontakt ze światem i daje pewność, iż kontakt ten może stanowić podstawę przekonania, że to, co dane w doświadczeniu jest zakotwiczone w zewnętrznej realności.

W moim przekonaniu zagadnienie to można odnieść do kwestii pojęciowej treści percepcji i jej związku z teoriopoznawczym realizmem, albowiem chcąc uprawiać filozofię percepcji i jednocześnie stać na stanowisku realizmu, trzeba przede wszystkim zastanowić się nad naturą treści percepcyjnej, czyli, czy ma ona jedynie empiryczną, czy także pojęciową określoność; czy treść ta jest zatem realna, wolna od ingerencji podmiotu, czy tė̇, będąc pojęciową, jest kłopotliwa (lub pomocna) dla obrony realizmu epistemologicznego.

Rozstrzygnięcie tego problemu poprzedzę twierdzeniem, które można nazwać tezą o warunku realności. Brzmi ona następująco: by uniknąć solipsyzmu wszystkie teorie percepcji muszą zawierać wspomniane wyżej aspekty I i II realizmu epistemologicznego (istnieje prawdziwy przedmiot postrzeżenia; przedmiot ów jest dany obiektywnie) — nawet jeśli teorie te nazwiemy idealizmem subiektywnym ${ }^{8}$, transcendentalnym idealizmem utożsamionym z empirycznym realizmem (I. Kant), fenomenalizmem (D. Hume, E. Mach, R.J. Hirst) czy teorią danych zmysłowych (B. Russell, G.E. Moore, H.H. Price) — każda z nich odwołuje się do rzeczywiście

8 Truizmem jest stwierdzenie, iż określenie filozofii Berkeleya jako subiektywny idealizm jest bardzo nieprecyzyjne: treści zmysłowe są obecne jedynie w umyśle, ale istnieją naprawdę, są realne, bo pochodzą od zewnętrznego autora i projektora — nieskończonego Ducha. 
istniejących i jednocześnie obiektywnie danych treści zmysłowych. Podmiot doznaje ich, ale nie są one efektem jego projekcji — w innym wypadku nie moglibyśmy mówić w ogóle o zmysłowej percepcji czegoś, lecz o przedmiotach wyobraźni. W moim przekonaniu nawet aspekt III realizmu epistemologicznego (przedmiot poznania istnieje jedynie poza sferą podmiotowa) nie pozostaje całkowicie zaniedbany czy odrzucony; on również pojawia się w tle wyżej wymienionych stanowisk, lecz potrzebuje „wsparcia” danej teorii percepcji pewnymi dodatkowymi elementami: metafizycznymi presupozycjami, przypuszczeniami czy wnioskami na bazie samej analizy postrzegania ${ }^{9}$. Można powiedzieć nawet, iż główne aspekty stanowiska epistemologicznego realizmu są niezbędne, by jakakolwiek teoria percepcji unikała niebezpieczeństwa solipsyzmu, była rdzeniem empiryzmu i co za tym idzie, była wsparciem dla nauk szczegółowych, dla których doświadczenie jest przecież niezbędnym narzędziem.

Kolejną kwestią wartą podkreślenia jest to, że realizm jakiejkolwiek teorii percepcji jest albo silny (realizm bezpośredni), albo umiarkowany (realizm pośredni, teoria danych, fenomenalizm, transcendentalizm Kanta) lub słaby (tak zwany idealizm Berkeley'a). Moim zdaniem w każdym z tych stanowisk treść percepcji jest: a) przedmiotem postrzeżenia; b) istnieje naprawdę, jest rzeczywiście dana w tym oto akcie postrzegania; c) ujawnia się niezależnie od podmiotu (nie jest przezeń projektowana); d) nawet jeśli ujawnia się tylko w sferze podmiotowej, to ma swoje odniesienie do zakładanej albo domyślanej lub wywnioskowanej sfery zewnętrznej — w tym choćby aspekcie, iż treści te nie pochodzą od podmiotu; on je percypuje jako zmysłowe postrzeżenie czegoś, co jest inne od niego samego. I nawet, gdyby wziąć pod uwagę postrzeżenia własnych stanów (doznania bieli czy goryczy), to są one stanami mającymi własną treściową określoność, która jest inna niż struktura podmiotu — są one dla niego naprawdę istniejącym przedmiotem doznania, są jego treścią doznaniową.

Elementy te świadczą o spełnieniu pewnego minimum realności percepcji, lecz jednocześnie mają także zaplecze podmiotowe — to znaczy, że percepcja jest zmysłowym odniesieniem się do realnej treści i jest jednocześnie rozpoznaniem jej jako poznawczego faktu, iż to, co postrzegam jest takie a takie, jest także konceptualnie ujmowane jako jakieś. Do tej ostatniej operacji podmiot potrzebuje jednak pojęciowego narzędzia detekcji i identyfikacji.

\section{Pojęciowa treści percepcji}

Zagadnienie pojęciowo określonej treści w zmysłowym postrzeganiu ma nowożytne źródła, choć zwykle wywodzone jest od kantowskiego transcendentalizmu, gdzie mamy wyraźną tezę o pojęciowo określonej naoczności i samorzutności myślenia,

${ }^{9}$ Najlepszym przykładem niech będzie teza fenomenalizmu Macha: rzeczy to myślowe kompleksy doznawanych „elementów” - ale te ostatnie są dane jako realne, pojawiają się bowiem w doświadczeniu, istnieją obiektywnie, są w relacjach i mają względnie stały charakter zjawiania się. „The world is our sensation" (E. Mach, On the Economical Nature of Physical Inquiry, [w:] idem, Popular Scientific Lectures (tłum. T.J. McCormack), Chicago 1895, s. 209) — odebranie realności rzeczom samym w sobie, poza kontekstem doświadczenia nie powoduje, że problem realności znika zupełnie, nawet w tak radykalnych teoriach percepcji jak fenomenalizm. 
które podporządkowuje sobie różnorodne treści i dokonuje ich syntezy. Bez powiązania treści z pojęciami te pierwsze byłyby ,ślepe" — nie miałyby żadnej wartości poznawczej. Jedność treściowo-pojęciową da się zauważyć już na poziomie samej zmysłowości, gdzie podmiotowa, przestrzenno-czasowa charakterystyka zawsze towarzyszy postrzeganiu, jest realna w odniesieniu do treści i idealna w odniesieniu podmiotowych źródeł. Fakt występowania podmiotowej aktywności syntetyzującej i jednoczącej ma miejsce poprzez pojęcia, które samorzutnie, dzięki schematowi transcendentalnemu, odnoszą się do zmysłowych treści i tym samym te ostatnie są im podporządkowane. Jest to o tyle istotne, że już nawet przestrzenno-czasowa charakterystyka postrzeganych treści ma wymiar zjednoczony (wszystko, co dane w percepcji jest zarazem przestrzenne i czasowe), a więc postrzeganie polega także na uruchomieniu jednoczacych operacji intelektualnych i schematu transcendentalnego. Jeśli zatem to, co postrzegane podlega wszystkim poziomom syntezy (od form zmysłowości, czystych pojęć, jedności apercepcji aż do czasowych schematów wyobraźni transcendentalnej), to realna, niezależna od podmiotu, niepojęciowa i czysto zmysłowa treści percepcji byłaby — podobnie do sfery rzeczy samych — tylko pomyślana lub założona jako zupełnie niezależna od podmiotu, lecz na poziomie postrzegania występowałaby jako realnie dana, ale zawsze już upojęciowiona.

W XX wieku problem natury treści percepcyjnej był głównie omawiamy przez W. Sellarsa i J. McDowella - ten pierwszy odrzucił koncepcję danych zmysłowych jako bezpośrednio uchwytywalnych, jakościowych, prywatnych elementów pośredniczących pomiędzy naszymi empirycznymi przekonaniami a samymi rzeczami. Takie proste zmysłowe istotności mogły się wydawać podstawowymi składowymi naszej wiedzy, pozbawionymi aspektu pojęciowego, lecz to, co postrzegamy twierdzi Sellars — to nie pojedyncze konkretności, lecz fakty, iż „coś jest takie a takie"10. Jednakże zwolennicy teorii danych, niepojęciowych, bezpośrednich elementów pierwotnych, będących fundamentem naszej wiedzy twierdzą, iż doznawanie zmysłowych minimów jako podstaw naszej wiedzy nie ma charakteru inferencyjnego i propozycjonalnego. Tym samym nie zawierają się w logicznej przestrzeni racji i są pozbawione pojęciowego elementu. Wtedy jednak nie ma przejścia od „doznaję" do wiedzy o tym doznaniu ${ }^{11}$ — i tym samym określenie ,wiedza zmysłowa" brzmi po prostu jak oksymoron.

Sellars odrzuca zatem mit danych głównie ze względu na aspekt rzekomego posiadania w postrzeżeniu bezpośrednio danych, pojedynczych, jakościowych istotności, które nie mogą wchodzić w zakres wiedzy. Nie możemy mówić o doznawanych indywiduach, lecz postrzeganych faktach — te ostatnie jednak są korelatem wiedzy, bo są już zawarte w logicznej przestrzeni racji, mówią tym samym o realnych zdarzeniach ${ }^{12}$. Jednocześnie łatwo zauważyć, iż krytyka mitu danych wskazuje także na trudności z precyzyjnym określeniem ontycznej realności danych i — co ważniejsze - że mit ów powoduje pogłębienie luki pomiędzy tym, co zewnętrzne

${ }^{10}$ W. Sellars, Empiricism and the Philosophy of Mind, [w:] Science, Perception and Reality, London 1963, s. 128.

${ }^{11}$ Por. ibidem, s. 128-129, 130-131.

12 Por. ibidem, s. 169. 
i empirycznie dane a sferą podmiotowej aktywności (sądów, wnioskowania i pojęć), a więc nie-empirycznej już, wiedzotwórczej pewności. Na poziomie epistemologicznym luka ta pokazuje, iż wciąż tkwimy w paradygmacie kartezjańskim, a tym samym nasze przekonania o realności, pewności doświadczenia są nadal podmywane.

McDowell z kolei podkreśla, iż logiczna przestrzeń racji jest w istocie przestrzenią pojęć ${ }^{13}$, lecz jednocześnie nie jest tak, że jedynie podmiotowa aktywność wiedzotwórcza jest jedyną bazą naszych przekonań o świecie. Drugą i konieczną stroną naszej wiedzy jest jej realny korelat - cała sfera przedmiotowa, a pomostem między umysłem a światem jest właśnie zmysłowa percepcja, która posiadając pojęciowy charakter, nie powoduje luki między podmiotem a sferą przedmiotową. Pojęciowa treść nie ma jednak tylko propozycjonalnego czy inferencyjnego charakteru — jest pojęciową treścią samej zmysłowości ${ }^{14}$, która manifestuje się w postrzeżeniu niejako „przed” podmiotową aktywnością w postaci wnioskowania czy wydawania sądów ${ }^{15}$. Sellars, powołując się na Kanta, podaje przykład postrzeżenia „ta kostka” i oczywistym powiązaniu owego postrzeżenia z treścią zdania „to jest kostka"16. W ten sposób postrzeżenie jakiegokolwiek przedmiotu $o$ - jeszcze przed wyprowadzeniem sądu o nim - zawiera informację o danym fakcie, a więc coś więcej niż samą tylko doznaniową określoność, daną jakiemuś podmiotowi. Idąc dalej, można powiedzieć więcej: całościowo ujmowana treść zmysłowa jest faktem dla postrzeżenia, dlatego że przedstawia już zsyntetyzowaną postać zarówno na poziomie doświadczania stanu rzeczy (,kubek stoi na biurku”), percypowania samego przedmiotu fizycznego („ten kubek”), jak i jego własności („ten kubek jest biały”). Wszystkie te aspekty przedmiotowości danej w percepcji charakteryzują się swoją realnością, ale zarazem są już uporządkowane — wyodrębnić z nich możemy nie tylko czysto empiryczne określoności, lecz także konieczne relacje.

Wbrew częstym krytykom pojęciowej treści nie chodzi tu zatem o twierdzenie, że by postrzegać kubek muszę już dysponować pewnym, ogólnie obowiązującym pojęciem kubka ${ }^{17}$. Chodzi raczej o wskazanie ogólnych określeń postrzeganego przedmiotu, już zawartych w percepcyjnej treści, których ujmowanie pozwala na rozpoznawanie przedmiotów jako realnych. Poza rozdzielnym potraktowaniem treści pojęciowej i niepojęciowej — jak podkreśla Gómez-Torrente — niezmiernie trudno je zdefiniować jako odrębne rodzaje ${ }^{18}$ — są one odmienne co do ilości informacji. Treść niepojęciowa ma ich więcej ${ }^{19}$, pojęciowa zaś manifestuje się jako stan przekonania podmiotu, że widziany przedmiot jest taki a taki. Jeśli tak, to większa ilość informacji treści niepojęciowej nie świadczy o jej odrębności od logicznej

13 J. McDowell, Mind and World..., s. 8.

${ }^{14}$ J. McDowell, Avoiding the Myth of the Given, [w:] John McDowell: Experience, Norm and Nature, J. Lindgaard (red.), Malden 2008, s. 5-6.

15 J. McDowell, Mind and World..., s. 61-62.

${ }^{16}$ W. Sellars, Science and Metaphysics. Variations on Kantian Themes, London 1968, s. 4-5.

17 T. Crane, The Nonconceptual Content of Experience, [w:] The Contents of Experience: Essays on Perception, T. Crane (red.), New York 1992, s. 143.

18 M. Gómez-Torrente, Report of an Unsuccessful Search for Nonconceptual Content, „Philosophical Issues" 9, 1998, s. 375.

${ }^{19}$ Por. ibidem, s. 379. 
przestrzeni racji, powiązania jej w relacje, nie daje także gwarancji, że realny świat wokół nas będzie miał — już na poziomie samego postrzegania — uporządkowany i strukturalnie zrozumiały charakter.

Stanowisko konceptualizmu w filozofii percepcji traktuje treść nierozłącznie: jest ona i empiryczna, i nieempiryczna. Z perspektywy myślenia o strukturze treści percepcyjnej są one odróżnialne, lecz jeśli potoczna intuicja wskazuje nam, iż świat doświadczenia nie jest rozdarty (inny na poziomie doznań, a inny na poziomie faktów), to oznacza, że to, co empirycznie dane jest jednocześnie uporządkowane według pewnych, stałych określeń ogólnych i tym samym rozpoznawane jako zrozumiałe. Innymi słowy, wersja konceptualizmu w filozofii percepcji, jaka jest prezentowana tutaj, głosi, iż w postrzeżeniu czegoś mamy do czynienia z pojęciową identyfikacją formalnych określeń sytuacji, rzeczy czy własności, a więc współwystępowania jedności treści ilościowych i jakościowych oraz przysługiwania ich jakiemuś przedmiotowi. Nie można zredukować postrzegania do subiektywnych doznań, albowiem to percepcja, a nie sama sensory awareness zawiera treść inferencyjną czy propozycjonalną ${ }^{20}$. Jednakże treść inferencyjna i propozycjonalna jest poprzedzona pojęciowym charakterem percepcji, który uwypukla także konieczne komponenty ogólne, określające postrzegane przedmioty, które występują zawsze razem z czysto zmysłowymi określonościami. Według autorów A New Framework for Conceptualism można pójść jeszcze dalej: to bycie własnością rzeczy i same relacje określają to, co jest czymś zmysłowym dla podmiotu, a nie treść doznaniowa $^{21}$. Wynika stąd, że niedoznaniowe treści, lecz ogólne aspekty są kluczowe dla realności rzeczy wokół nas — własność jest czymś, co przysługuje przedmiotowi, relacje zaś dokonuja powiązania percypowanego przedmiotu w jedność. Treść jako taka nie jest naszym konstruktem, ale nie jest też dana poza kontekstem naszych intelektualnych narzędzi. W ten sposób biały, owalny kubek stojący na biurku przede mną jest postrzegany jako powiązana, współwystępująca jedność percypowanych treści zmysłowych i ogólnych określeń. Dopiero tak zrozumianemu doświadczeniu opartemu na koncepcji pojęciowej treści można przypisać prawdziwość lub fałszywość, zaś samo doznawanie czegoś jest poza taką weryfikacją. Te ogólne określenia percypowanych przedmiotów są już obecne w percepcji, ale nie są empiryczne, stanowią podstawę do stosowania pojęć pochodnych i ostatecznie można przyjać, iż stanowią ekwiwalent kantowskich predykamentów. Pojęcia pochodne byłyby pojęciami typu „kubek” czy „,biurko”; te pierwotne miałyby charakter korelatów konstytutywnych relacji w rzeczach: współwystępowania, jedności określeń ilościowo-jakościowych w tym przedmiocie i przysługiwania (bycia cechą czegoś).

\section{Pojęciowa treść percepcji a realizm}

Jeśli przyjaćc, iż przedmiotem naszego postrzegania są sytuacje czy stany rzeczy (ten kubek stoi na biurku), to percypujemy coś już uwikłanego w relacje - coś

${ }^{20}$ Por. J. Bengson, E. Grube, D.Z. Korman, A New Framework for Conceptualism, „Noûs” 45(1), 2011, s. $169-170$.

${ }^{21}$ Por. ibidem, s. 170. 
konkretnego właśnie dlatego, że danego nam jako pewna, całościowa perspektywa, w której obecne są zmysłowe treści i w miarę stabilne powiązania między nimi. Możemy także uznać, iż spostrzegamy same fizyczne przedmioty (kubek), gdy posługując się uwagą, wyróżniamy go z pola naszego oglądu. Dopuszczalne jest również twierdzenie, iż percypujemy same własności rzeczy (na przykład kształt czy kolor tego kubka) i to one będą wydawać się pojedynczymi elementami zmysłowego oglądania. Mamy tu więc do czynienia z percepcją na jakimś poziomie konkretu: stanu rzeczy, samych obiektów fizycznych czy ich własności. Niezależnie od tego, do którego z tych poziomów odnosi się nasze postrzeganie, to percypujemy pewne treści, które są nie tylko realne, obiektywne i różnorodne, ale jednocześnie są złożone w wiele stałych powiązań, które jako ogólne „niezmienniki doświadczenia" stanowią korelat pojęciowej aktywności podmiotu w momencie postrzegania. Jeśli owe „niezmienniki doświadczenia” wraz ze zmysłowymi treściami wydają się współkonstytuować przedmioty postrzeżenia, to pojawić się musi pytanie: co decyduje o realności przedmiotu percepcji? Tylko jej niepojęciowa treść empiryczna, czy także relacyjny charakter występowania tych treści, a więc pewne ogólne własności przedmiotów postrzeżenia?

Wydaje się, iż pewną ukrytą tezą empirycznego fundacjonalizmu i stanowisk odrzucających funkcjonowanie pojęciowej treści percepcji jest twierdzenie, iż realność tego, co dane w percepcji zależy wyłącznie od doznaniowego komponentu, bo to on stanowi probierz obiektywności i wydaje się adekwatny do własności przedmiotów samych ${ }^{22}$. W moim przekonaniu jednak, jeśli zasadne jest uznanie funkcjonowania pojęciowej treści percepcji to realność (rzeczywistość, obiektywność) przedmiotu postrzeżenia jest w równym stopniu zależna od treści zmysłowych, jak i od owych „niezmienników doświadczenia” — i co za tym idzie — oba te komponenty są nieizolowalne, choć mogą być pomyślane jako odrębne.

Kiedy twierdzę, że treści zmysłowe występują zawsze w pewnym powiązaniu z owymi „niezmiennikami doświadczenia”, to mam na myśli, że treści te ukazują się nam w różnorakich relacjach i dzięki temu mogę powoływać się na proste przykłady: gładkość i chłód kubka, jego owalny kształt i biała barwa. W takich przykładach chodzi zarówno o wskazanie samych treści zmysłowych, jak i podkreślenie ich współwystępowania, gdzie jako jedność różnorodnych cech jakościowych wraz z ilościowymi stanowią przestrzenny i czasowy obiekt dany w tym-oto postrzeżeniu. O współwystępowaniu i jedności można jednak mówić dwojako:

1. empiryczne treści są powiązane z sobą (ilościowe z jakościowymi), na przykład owalny kształt wraz z białą barwą;

2. empiryczne treści są powiązane i stanowią całość z przedmiotem — owalny kształt i biała barwa przynależy do fizycznego obiektu (kubka). Relacja przysługiwania (bycia własnością czegoś) zawierałaby się właśnie w tym elemencie.

Oba aspekty relacji są podkreśleniem tego, co Twardowski nazywał formalnymi składnikami przedmiotu przedstawienia. Pierwszy byłby formalnym składnikiem

${ }^{22}$ Pomijam w tym momencie to, iż już sama konstrukcja adekwacji musi z góry zawierać pojęciową konstrukcję przypisującą percypowaną, niepojęciową treść do odpowiadającego jej faktycznego stanu świata. 
drugorzędnym, drugi zaś formalnym składnikiem pierwszorzędnym² ${ }^{23}$. Jeśli zatem przyjąć, iż współwystępowanie, jedność oraz powiązanie treści względem siebie i względem całości przedmiotu (przysługiwanie mu) stanowią istotne relacje określające, czym jest przedmiot postrzeżenia, to po pierwsze, relacje te są owymi realnymi „niezmiennikami doświadczenia”, a ich podmiotowymi korelatami są nasze pojęcia; po drugie, ujęcie jakiejkolwiek treści niepojęciowej jest rezultatem abstrahowania, gdzie pomija się konieczne powiązania w postaci relacji i tym samym pragnie się ująć jakieś wyizolowane zmysłowe minima, rzekomo dane w jakimś konkretnym oglądzie. Konsekwencją tezy o niepojęciowej treści będzie twierdzenie, iż treści percepcyjne ujmowane jako dane nam minima stanowią najistotniejsze (a nawet jedyne) kryterium realności rzeczy wokół nas.

Tymczasem konceptualizm w filozofii percepcji, jaki tutaj przedstawiam, zachowując tradycyjny podział na materię (treść) i formę (sposób) percepcji, przyjmuje, iż sytuacje (zdarzenia), przedmioty fizyczne i same własności rzeczy są nam dane wraz z relacjami, te zaś stanowią formalne komponenty przedmiotów zmysłowych i jako takie są korelatami naszej identyfikacji tego, co postrzegamy, już w samym momencie percypowania tego czegoś. A zatem owa identyfikacja odbywa się nie na poziomie „odrębnej” operacji, wnioskowania, lecz musi być już obecna w każdorazowym postrzeżeniu czegoś. Dzięki temu, doznając owalności, twardości, chłodu i białości danego mi przedstawienia, wiem, że przede mną stoi na biurku realny przedmiot (biały kubek).

Moim zdaniem na tak zarysowanej płaszczyźnie problemowej można zaryzykować tezę, iż stanowisko broniące conceptual content jest dobrym narzędziem wspierajacym epistemologiczny realizm, albowiem:

- spostrzeganie jest ujęciem obiektywnie istniejących sytuacji czy rzeczy, ich własności zaś są realnie ,posiadane”, a więc: cecha $F$ przysługuje rzeczy $o-$ wyrażamy zatem twierdzenie dotyczące stosunku pewnego percypowanego aspektu (zmysłowej treści) do całości rzeczy. Nazwę tego typu stanowisko realizmem mocnym (RM);

— zakładając, iż spostrzeganie nie jest ujęciem sytuacji, rzeczy czy jej własności, lecz jest zupełnie odrębnym od jakiegokolwiek zewnętrznego przedmiotu uchwyceniem jakiejś danej zmysłowej, pewnej percepcyjnej jakości (na przykład konkretnego wrażenia czerwieni lub twardości): postrzegamy treść, która nie ujawnia się w relacji do całości jakiejś rzeczy; nie przyjmujemy od razu, iż przysługuje rzeczy, lecz występuje po prostu jako pewna dana nam tu-oto zmysłowa jakość. Tutaj percepcja jest rozumiana jako ujmowanie tego, co dane, z późniejszym uwzględnieniem przynależności tych treści do jakiegoś wywnioskowanego, zewnętrznego przedmiotu. Postrzeżenie zachowuje realny komponent — treść jest obiektywnie dana jako coś jedynie zmysłowego i dopiero potem odniesione do zewnętrznej sytuacji czy rzeczy. To stanowisko można nazwać realizmem słabym (RS).

RM jest charakterystyczny dla realizmu bezpośredniego w filozofii percepcji. Drugi zaś (RS) zwykle towarzyszył formułowaniu tez teorii danych zmysłowych,

${ }^{23}$ K. Twardowski, O treści i przedmiocie przedstawien, tłum. I. Dąbska, [w:] Wybrane pisma filozoficzne, Warszawa 1965, s. 42-43, 48-50. 
fenomenalizmowi czy (paradoksalnie) idealizmowi. Oba typy stanowisk (RM i RS) zawierają realną treść zmysłową, bo są zgodne ze wspomnianymi fundamentami realizmu epistemologicznego i mówią o:

— realnym/rzeczywistym/prawdziwym istnieniu czegoś, co jest przedmiotem poznania;

— przedmiot ów jest dany obiektywnie.

Różnice między RM a RS dotyczą twierdzenia III (przedmiot istnieje jedynie poza sferą podmiotową). W ramach RS można jedynie powiedzieć, iż treść doświadczenia jest albo wszystkim, co istnieje i nie jest powiązana z zewnętrzną wobec podmiotu rzeczywistością (fenomenalizm, idealizm), albo ta ostatnia jest reprezentowana w podmiocie, jest zakładana (postulowana) lub jest wywnioskowana (realizm pośredni, teoria danych). Trzecia teza realizmu epistemologicznego była ostatecznie kłopotliwa dla nowożytnego, empirycznego ideizmu wskazującego, że treści zmysłowe jako idee są obecne jedynie w umyśle (J. Locke, G. Berkeley, D. Hume) i dla teorii danych zmysłowych.

Jednakże moim zdaniem obie wersje realizmu (RM i RS) są możliwe, o ile uznamy, iż w naszym doświadczeniu jakakolwiek treść zmysłowa jest nie jest całkowicie odrębnym elementem od pojęciowego. Można zauważyć bowiem, iż zarówno w RM, jak i w RS mamy do czynienia z percepcyjnym ujmowaniem realnych i obiektywnych treści zmysłowych (choć nie zawsze są uznawane za zewnętrzne), ale są one dane wraz z relacyjną, pojęciowo wyrażalną charakterystyką:

- postrzegane treści zmysłowe są dane w relacjach: współwystępowania treści i jedności ilościowo-jakościowej — RM i RS;

— treści te są korelatami własności rzeczy przysługującej przedmiotowi — korelacja jest aktem intelektualnej identyfikacji, że treści F1, F2, F3 stanowią wspólnie zestaw własności przedmiotu o (relacja przysługiwania) — tylko RM.

W ramach RS nie ma kłopotu z relacjami jedności i współwystępowania, lecz z relacją przysługiwania percypowanych własności do realnego przedmiotu fizycznego. Jednocześnie gdy mówię o jakimś rzekomo pojedynczym doznaniu poprzez użycie zaimka nieokreślonego („widzę coś białego”), to owo wyrażenie wydawałoby przejawem percypowania samej treści, której właśnie nic określonego (poza nią samą) nie przysługuje, i że nie występuje ona w jakimś relacyjnym związku z innymi aspektami postrzegania. Jest tu jednak niejawnie obecne „Ja wiem, że widzę coś białego" oraz że owo coś ma taką właśnie, zmysłową charakterystykę (jest takie a takie). Określenia: białe, biel, biała dana zmysłowa czy biała plama są wyrażeniami przymiotnikowymi i rzeczownikowymi w odniesieniu do: czegoś, co jest mi dane w tym oto postrzeżeniu; czegoś, co jest czymś jakościowym, ale ta jakościowa określoność nie wyczerpuje jej „bycia danym”. Jest ona przedmiotem wiedzy „Ja wiem, że to coś jest takie a takie". Oznacza to, że treść ta jest mi realnie dana i jest w relacji do mojego przekonania, że jawi mi się tak a tak. Pojęciowy aspekt percepcji jest więc zachowany w ramach RS.

Jednocześnie skoro można powiedzieć, iż percepcja dostarcza nam informacji o rzeczach wokół nas i umożliwia zarazem to jak wiemy o tych rzeczach ${ }^{24}$, to w per-

${ }^{24}$ Por. B. Brewer, Foundations of Perceptual Knowledge, „American Philosophical Quarterly” $34(1), 1997$, s. 52. 
cepcji przedmiotu o zawierają się komponenty: treść i podmiotowa aktywność wiedzotwórcza. Jednak jeśli wypowiedź taka jest weredyczna, to nie tylko na poziomie wypowiedzi mamy do czynienia z pojęciowym rozpoznawaniem, że przedmiot $o$ jest $F$ - już w trakcie postrzegania wiemy, że $o$ jest $F$, czyli rozpoznajemy, że ma miejsce taki a taki stan rzeczy, że dana mi treść ma taki a nie inny charakter i że identyfikuję ją jako taką, a nie inną. Zatem nie tyle nadajemy pojęciowy charakter uprzednio doznanym treściom, ale są one już także relacyjne ${ }^{25}$ i jako takie mają charakter warunków postrzeżenia zarówno realnych sytuacji, rzeczy, czy ich własności, ale także w przypadku rzekomo wyizolowanych, rzekomo niepojęciowych czystych danych, w ich ilościowo-jakościowej jedności. Te warunki postrzeżenia są zewnętrzne, czyli nie sa podmiotowe; sac realne, ale w percepcji są podmiotowo (pojęciowo) rozpoznawalnymi określeniami faktów.

Niezależnie zatem od różnic w stanowiskach w ramach zarówno RM, jak i RS można zauważyć, iż w trakcie każdorazowego doznawania jakiejś „białej danej”" towarzyszą jej także elementy pojęciowe, a więc, że owo „białe” zawsze współwystępuje z jakimś kształtem, wielkością, pojawia się w przestrzenno-czasowym uporządkowaniu (teraz i tutaj), obecne jest dzięki rozróżnianiu treści na tle innych i stanowi z nimi jakiś stan rzeczy. Miłośnik fenomenalizmu czy idealizmu, unikając urzeczowienia doznań czy wypowiedzi dotyczących założonej ontologii świata zewnętrznego, może użyć neutralnego określenia, na przykład ,,jest mi dana biała plama i jest ona tym i tylko tym co dane w tym oto oglądzie". Jednak łatwo zauważyć, iż każdy tego typu obiekt ma jakiś kształt czy wielkość, a te aspekty nie są czymś tylko zmysłowym, bo wyrażają stosunek poszczególnych linii i płaszczyzn, które je tworzą, zaś wszelkie stosunki są czymś pojęciowo ujmowanym i nie stanowią czysto zmysłowo-jakościowego uposażenia. Jeśli tak, to strumień doznań dany w oglądzie sprowadzałby się na przykład do pewnego trwania białej treści zmysłowej, a więc czasowego uporządkowania oraz do równoczesnego współwystępowania wraz z innymi doznaniami. Czasowość czy współwystępowanie nie są jednak elementami o charakterze treści zmysłowych. W taki sam sposób fakt występowania treści na tle innych polega na byciu w relacji, relacje zaś są elementami pojęciowymi, choć zawartymi w doświadczeniu zmysłowym.

Relacyjny charakter „bycia razem” zmysłowych treści nie jest „,nakładany” przez podmiot czy tylko domyślany w stosunku do rzekomo niepojęciowej treści percepcyjnej. Nie jest też czymś o charakterze jedynie propozycjonalnym czy inferencyj-

\footnotetext{
${ }^{25}$ Podobny pomysł wysunął już W. James, który dyskutując głównie z klasycznymi, brytyjskimi empirystami i podważając ich metafizyczne błędy, wskazał jednocześnie na relacyjny charakter empirycznego poznania (por. W. James, Essays in Radical Empiricism, Lincoln 1996, s. 44). Zarazem gdy akcentował realność relacji i starał się odsuwać idealistyczne roszczenia F.H. Bradleya, postulował istnienie pierwotnego doświadczenia, pozbawionego upojęciowionej postaci, w którym nie ma wyróżnionych elementów (minimów). Jest ono całościowe, ,czyste”, nieintencjonalne, nieokreślone (Por. ibidem, s. 93), ufundowane na jakimś faktycznym that, które będąc dopiero w relacjach, ujawnia się w swojej konkretności i ujmowane w postaci quasi-metafizycznej, czasowej ciągłości (Por. ibidem, s. 49-50). Problemem pozostaje więc — w moim przekonaniu — rozumienie konkretności „czystego doświadczenia”. Jeśli jest ono na przykład czystym doświadczeniem pokoju, to jest ono konkretne, przy specyficznie podmiotowej zdolności uchwytywania procesualnego strumienia relacyjnie spójnych doznań. Jeśli jednak jest ono ujęciem czystego that, to ono samo jako nieokreślone nie jest konkretne, a swoją konkretyzację uzyskuje dopiero w kontekście relacji.
} 
nym. Relacyjna jedność i współwystępowanie treści są już obecne w percepcji, bo sytuacje, rzeczy i ich własności stanowią stały i zjednoczony stan świata wokół nas. Ujmowanie treści niepojęciowej i pojęciowej aktywności podmiotu jako odmiennych, odseparowanych elementów poznania skutkowałby dość osobliwą tezą, iż w percepcji mamy do czynienia ze zbiorem rozproszonych treści, które jawią się jako czysto doznaniowa zawartość percepcji, a jej zjednoczony i stały stan uzyskujemy dopiero na poziomie aktywności intelektualnej. Prowadziłoby to tym samym do uznania, iż rzeczywistość ma stały i uporządkowany charakter wyłącznie dzięki myśleniu, a na poziomie postrzegania rzeczywistość jest co prawda niezależna od podmiotu, ale jest na tyle chaotyczna i nieprzejrzysta, że nie jawiłaby nam się jako zbiór faktów (sytuacji, rzeczy i ich własności). Takie dualne rozumienie aspektów postrzeżenia musiałoby także prowadzić do założenia o zróżnicowanym charakterze realności tego, co postrzegane. Doznaniowa treść niepojęciowa byłaby realnością jakiegoś innego typu niż realność treści ujmowanej jako zjednoczona, współwystępująca i relacyjna. Przyjęcie odmiennych rodzajów realności (nierelacyjnej i relacyjnej) prowadziłoby z kolei do dalszej problematyzacji — jeśli tylko niepojęciowa treść byłaby realna we właściwym znaczeniu (zgodna z powyższymi aspektami I-II-III), to realność sytuacji, rzeczy wokół nas i ich własności miałaby jedynie status domyślany. Kłopot w tym, iż o ile łatwo wskazać na przykłady percepcyjnych treści zawierających już relacyjny i pojęciowy charakter (kubek stoi na stole; ten kubek jest biały; białość kubka), o tyle trudno jest podać konkretny przykład niepojęciowej treści nie tyle wyabstrahowanej z percepcyjnego kontekstu, lecz realnie danej w postrzeżeniu jako intersubiektywnie dostępny fakt. Próba wskazania na doznanie jakiejś treści, pewnej czysto zmysłowej impresji jako prywatnie dostępnego przedmiotu zmysłowej świadomości, spowodowałoby, iż percepcja zostałaby zredukowana na doznawania wewnętrznych stanów, nie można byłoby jej zweryfikować, nigdy nie byłaby łącznikiem ze światem, a koncepcji takiej groziłby solipsyzm. Można nawet zaryzykować twierdzenie, iż postrzeżenia o charakterze iluzji czy halucynacji zawierają relacyjny kontekst (jedność i współwystępowanie) i choć nie mają weredycznego związku z faktami, to zachowują swój pojęciowo określony komponent. Relacyjny charakter postrzeganych treści zostaje więc nawet w przypadku iluzji i halucynacji zachowany, lecz nie występuje tu relacyjny i adekwatny związek ze światem. Inaczej mówiąc, każda treść percepcji jest pojęciowa, choć nie każda pojęciowa percepcja jest wyrazem weredycznego ,raportu o stanie świata”.

B. Brewer wskazał na pewne kłopoty związane ze stanowiskiem conceptual content, albowiem jest ono z góry nakierowane na samą treść, a nie na to, co w empirycznie naturalny sposób jest nam dostępne — realnym przedmiotom. Brewer wskazuje na dość istotną kwestię mającą obronić klasyczny empiryczny realizm przed meandrami konceptualizmu. Jeśli bowiem przedmioty fizyczne są niezależne od umysłu (realizm ontologiczny) i przedmioty te są bezpośrednimi przedmiotami percepcji (realizm epistemologiczny), to jednocześnie nie można uznać, iż bezpośrednie przedmioty percepcji mają charakter mentalny (idee zmysłowe, dane, czy qualia), bo są podmiotowe i zależne od umysłu (klasyczny anty-realizm epistemo- 
logiczny $)^{26}$. Zdaniem Brewera, by pozbyć się tej aporii należy uznać, iż świadomość postrzegająca jest rozpoznawaniem, że przedmiot $o$ jest $F$ i dzięki temu może ona zastosować pojęcie $F$ do $o$. Jego zdaniem jeśli konceptualizm w filozofii percepcji ma być wiązadłem oglądu treści na poziomie wnioskowania, to już samo odniesienie się do owej treści jest ryzykowne, bo prowadzi do uznania, iż percypujemy coś, co musimy zjednoczyć i zestawić do postaci przedmiotów dopiero na poziomie myślenia. By utrzymać realizm epistemologiczny na poziomie percepcji wystarczy nam odniesienie się do realności w postaci oglądu przedmiotu (a nie treści) i dlatego należy zmienić koncepcję relacji między percepcyjnymi przekonaniami o przedmiocie $o$ a wnioskowaniem poprzez pojęcia. Właściwa, bezpośrednia i werydyczna percepcja zewnętrznych przedmiotów fizycznych wynika — zdaniem Brewera — z samej natury percepcji jako conscious acquaintance. A ona przede wszystkim bezpośrednio ujmuje przedmioty same. Jednakże na podstawie postrzeżenia wiemy, że przedmiot $o$ jest $F$, o ile jest on dany w przestrzenno-czasowym ujęciu czy dzięki rozpoznaniu, że przedmiot $o$ posiada własność $F^{27}$. Jeśli postrzegamy $o$ to jednocześnie przedmiot ów zawiera istotne podobieństwa do pewnego ogólnego wzorca (o-like) i tym samym dokonujemy aplikacji pojęciowego rozpoznania, iż o jest tym, czym jest ${ }^{28}$. Bez takiej podmiotowej aktywności nadal tkwilibyśmy w dualizmie doznawanych, wewnętrznych treści i odrębnym światem zewnętrznych przedmiotów. Jeśli jednak percepcja jest nakierowaniem na świat, to doznawane treści są treściami jakiegoś zewnętrznego przedmiotu, który jest ujmowany jako ten a nie inny, właśnie ze względu na rozpoznawalne w nim, zmysłowe istotności, które są zjednoczone i współwystępujące. Propozycja Brewera wydaje się odsuwać roszczenia skrajnego konceptualizmu (konstruktywizm w wersji inferencyjnej) i dotyczy relacji podmiotu ze światem ${ }^{29}$. Brewer jednakże nie odcina się od umiarkowanej wersji konceptualizmu — nie tylko sama relacja podmiotu względem świata jest warunkiem percepcji, ale także aplikacja pojęć $c^{30} \mathrm{w}$ postrzeganiu przedmiotów, które jawią się jako istniejące realnie w pewnym stałym uporządkowaniu.

\section{Podsumowanie}

Łatwo zauważyć, iż budowanie modeli w ramach filozofii percepcji często wymaga odniesienia do przykładów, co już w pewien sposób ułatwia realistyczną orientację jakiegokolwiek stanowiska, nawet tego, które podkreśla obecność pojęciowej treści. Przykłady te muszą być intersubiektywnie zrozumiałe, to znaczy, muszą być przynajmniej potencjalnie dostępne jako realne i empiryczne. Pomijając jednak ten czynnik sprzyjający, należy przede wszystkim podkreślić, iż stanowisko konceptualizmu w filozofii percepcji odgrywa dwie główne role. Pierwsza z nich dotyczy związku zachodzącego między percepcją a wiedzą zmysłową i sprowadza się do tezy: by

\footnotetext{
${ }^{26}$ Por. B. Brewer, Perception and its Objects, Oxford 2013, s. 1-14.

27 Por. ibidem, s. 96-97, 118-119.

28 Por. ibidem, s. 120-121.

${ }^{29}$ Por. ibidem, s. 93.

30 Por. ibidem, s. 157.
} 
poznanie empiryczne mogło stanowić bazę dla poznania naukowego, percepcja musi mieć pojęciowy charakter, gdyż w innym wypadku nie będzie przejścia od doznań treści do tego, co Sellars i McDowell nazywają przestrzenią racji. Wiedza percepcyjna jest więc już zawarta w samym postrzeganiu, bo jest ono pojęciową identyfikacją, że postrzegany $o$ jest taki a taki i ostatecznie nie ma różnicy między „doznaję x" a stanem ,wiem, że doznaję x". Teza o pojęciowej treści percepcji odgrywa jednak drugą, rzadko zauważalną rolę — jeśli wraz z „mitem danych” odrzucimy przekonanie o istnieniu pojedynczych minima sensibilia, które jako czysto jakościowe określoności zmysłowe są rzekomo dane w postrzeżeniu, to okaże się, że treść percepcji stanowi zawsze pewną złożoną, ilościowo-jakościową charakterystykę i tym samym jej relacyjną jedność. Relacje te tworzą całościową strukturę przedmiotu postrzeżenia, stanowią o jego uporządkowaniu i dzięki nim percepcja jest także detekcją, iż to, co postrzegane jest faktem, a więc ma realny charakter.

Konceptualizm w filozofii percepcji jest więc tu rozumiany jako stanowisko odrzucające redukowanie postrzegania do wewnętrznych stanów podmiotu. Dlatego też to pojęciowa treść percepcji jest przede wszystkim treścią reprezentacyjną, właśnie dlatego że manifestuje nie tylko empiryczną, jakościową charakterystykę tego, co postrzegane i tym samym nie sprowadza percepcji do podmiotowych doznań. Treść percepcji ujawnia także konieczne relacje konstytuujące stany rzeczy, obiekty fizyczne i ich własności. Relacje te są realnymi prawidłowościami, warunkującymi niezmienność i tożsamość postrzeganych przedmiotów — dzięki nim czysto empiryczna, jakościowa określoność nie rozpada się w postrzeżeniu i nie manifestuje się tė̇ jako zatomizowane minima sensibilia.

Stanowisko dotyczace pojęciowego charakteru treści percepcji odrzuca tezę o jakościowo i szczegółowo określonej treści, która ze względu za swoją różnorodność wymyka się naszemu pojęciowemu identyfikowaniu. Zarzut ten zwykle przytaczany jest, gdy wspomina się o naszej czysto zmysłowej zdolności odróżniania odcieni barw, które nie mają swoich pojęciowych korelatów. Jednak ten sam przykład wskazuje, że sama czynność odróżniania odcienia przedmiotu F1 od F2 nawet jeśli nie wymaga użycia pojęcia różnicy, to uwypukla obecną w postrzeżeniu aktywność intelektualnego rozpoznawania, iż odcień $F 1$ jest rzeczywiście inny od F2. W ten sposób samo działanie percepcji jest traktowane nie jako czysto doznaniową odbiorczość jakiejś treści, lecz jako proces uchwytywania zmysłowych określoności wraz z ujmowaniem ogólnych prawidłowości, które w równym stopniu co treść decydują o tym, czym jest postrzegany przedmiot. W tym też sensie percypowana treść jest szczegółowo złożona (fine-grained) nie tylko na poziomie czysto zmysłowym - jest ona taka, bo składa się z bogatego doznaniowego elementu zmysłowego i konceptualnego.

Pojęciowa treść percepcji nie podmywa realizmu epistemologicznego — jest dla niego wsparciem. Relacje: współwystępowania treści, jedności ilościowo-jakościowej i powiązania treści z sobą i z przedmiotem oraz pewna relacja kardynalna obejmująca te poprzednie: różnica podmiotowo-przedmiotowa ${ }^{31}$, w ramach której zachodzi

${ }^{31}$ Relacja kardynalna potwierdza transcendentalny, pojęciowy charakter percepcji, wyrażony także w znanym rysunku z Traktatu Wittgensteina. Świadomość percepcyjna jest dlatego intencjonalna, że 
postrzeganie - wszystkie te pojęciowo określone komponenty odnoszą się do struktury treści percepcyjnej i stanowią swoiste „przęsła realności” empirycznych treści ${ }^{32}$. Percepcja jest nakierowana na realny obiekt (sytuacje, rzeczy i ich własności), niezależnie od tego, co różne teorie percepcji uznają za przedmiot postrzeżenia. Każde ze stanowisk w filozofii percepcji musi zachować pewien komponent odniesienia się do realności, bo w innym wypadku nie można byłoby mówić o postrzeżeniu zmysłowym, lecz jedynie o doznawaniu wewnętrznych stanów podmiotu. I jeśli trzymać się perspektywy percepcji jako otwartości na świat, to świadomość postrzegająca jest jakby snopem światła rzucającym się na zewnętrzny przedmiot i ujmująca go w swoich ramach, ale strumień tego oglądu nie jest czysty, lecz jest wyposażony w pojęciowe instrumenty odniesienia, dzięki którym ujmujemy sytuacje, zdarzenia, rzeczy czy ich własności wraz z ich nie-empiryczną, ogólną strukturą relacyjną.

Jeśli zaś w ramach RS mamy do czynienia z percypowaniem nie tyle stanu rzeczy czy samego przedmiotu fizycznego, lecz jakiejś danej własności (na przykład biała dana zmysłowa, białość sama), która wydaje się percypowana jako coś wyłącznie jakościowego, wyizolowanego od relacyjno-pojęciowej identyfikacji, to $\mathrm{RS}$ w filozofii percepcji musi także uznać istnienie niezależnych od podmiotu treści (bo mówimy tutaj o empirycznym postrzeganiu a nie projektowaniu treści) czy choćby odróżniać czysto doznaniową treść „, umyśle” od samego umysłu. Treść ta z perspektywy RS nadal jednak będzie manifestować się jako relacyjno-pojęciowa - doznanie bieli nie jest samoistne, jawi się w swojej jakościowo-ilościowej jedności: ma jakiś kształt, wielkość, natężenie, odcień; jest bielą, ale jest jeszcze jakaś. Innymi słowy, nawet gdyby przyjąć, iż w ramach RS odnosimy się do samego empirycznego doznania treści (jakiejś białości), to jej bycie danym nie sprowadza się tylko do jednej jakościowej określoności, wymaga podmiotowej uwagi, gdy identyfikowana jest w swojej określoności, różnicuje się na tle jakichś innych czy występuje w kontekście określeń ilościowych: ma swoje ograniczone pole występowania, objętość itp.

Konceptualizm w odniesieniu do treści percepcji nie musi posiłkować się metafizycznymi teoriami przedmiotów indywidualnych jest jednak pomocnym narzędziem $\mathrm{w}$ aplikacji tychże teorii na gruncie filozofii percepcji. Już w postrzeżeniu mamy bowiem do czynienia ze złożonymi przedmiotami postrzeżeń: są one z perspektywy myślenia o strukturze przedmiotu postrzegania treściowo-relacyjne; a z perspektywy samej percepcji formalnym wiązadłem ich treści jest jedność, współwystępowanie i przysługiwanie przedmiotowi. Bez odniesienia się do tej treściowo-relacyjnej złożoności, odkrywanej dzięki pojęciowym zdolnościom podmiotu, metafizyczne

\footnotetext{
jako taka jest zawsze w ramach relacji podmiotowo-przedmiotowej, ale jednocześnie jest odwróconą intencjonalnością — percepcja jest percepcją czegoś, ale świadomość percepcyjna jest świadomością, o ile jest jej przedstawiony, dany, a więc przeciwstawiony przedmiot.

${ }^{32}$ Koncepcja podmiotowości warunkującej bezpośredni kontakt z empirycznymi przedmiotami nie jest czymś nowym, ale nawet jako propozycja daleka od RM w filozofii percepcji wskazuje na dość istotną kwestię: metafizyczne warunki brzegowe relacji poznawczej — postrzegający podmiot nie tylko doznaje, lecz także poprzez użycie pojęciowych „niezmienników doświadczenia” podtrzymuje to, co dane, utrwala je, współ-konstytuuje jako powiązane, współwystępujące w pewnej jedności treści, o przestrzenno-czasowym charakterze (Fichte, Hegel).
} 
teorie przedmiotów indywidualnych pozbawione byłyby epistemologicznego wsparcia. Innym aspektem jest specyficzne powiązanie, jakiego dokonuje koncepcja pojęciowej treści: z jednej strony oddaje hołd fenomenalnemu charakterowi naszej percepcji (treści są w nas), z drugiej zaś pojęciowy komponent pozwala nie tylko konstruować przekonania o świecie (w sądach), lecz także dawać wyraz realnym, choć ogólnym relacjom, określającym strukturę rzeczy wokół nas. Innymi słowy, konceptualizm w wersji prezentowanej tutaj nie przyjmuje, iż pojęcia nadawane są na zewnętrzną, czysto empiryczną treść percepcji, lecz są obecne jako podmiotowa zdolność identyfikacji realnej, choć formalnej struktury percypowanego przedmiotu. Dzięki temu stanowisko to pozwala wyjaśnić dlaczego już na poziomie percepcji możemy mieć do czynienia z sytuacjami, rzeczami i ich własnościami jako czymś, co jest empirycznie dane i jednocześnie intersubiektywnie rozpoznawane jako realny i względnie stały stan świata wokół nas.

\section{Bibliografia}

Bengson J., Grube E., Korman D.Z., A New Framework for Conceptualism, „Noûs” 45(1), 2011, s. $167-189$.

Brewer B., Foundations of Perceptual Knowledge, „American Philosophical Quarterly” 34(1), 1997, ss. 41-55.

Brewer B., Perceptual Experience Has Conceptual Content, [w:] Contemporary Debates in Epistemology, M. Steup, E. Sosa (red.), Malden2005, s. 217-230.

Conduct M.D., Naïve Realism and Extreme Disjunctivism, „Philosophical Explorations” 13(3), 2010, s. 201-221.

Crane T., The Nonconceptual Content of Experience, [w:] The Contents of Experience: Essays on perception, T. Crane (red.), New York 1992, s. 136-157.

Gómez-Torrente M., Report of an Unsuccessful Search for Nonconceptual Content, „Philosophical Issues" 9, 1998, s. 369-379.

James W., Essays in Radical Empiricism, Lincoln 1996.

Johnston M., How to Speak of the Colors, „Philosophical Studies: An International Journal for Philosophy in the Analytic Tradition" 68(3), 1992, s. 221-263.

Mach E., On the Economical Nature of Physical Inquiry, [w:] idem, Popular Scientific Lectures (tłum. T.J. McCormack), Chicago 1895, https://archive.org/details/cu31924012322354/ page/n219

McDowell J., Avoiding the Myth of the Given, [w:] John McDowell: Experience, Norm and Nature, J. Lindgaard (red.), Malden 2008, s. 1-14.

McDowell J., Mind and World. With a New Introduction, Cambridge1996.

McDowell J., Perceptual Experience: Both Relational and Contentful, ,European Journal of Philosophy" 21(1), 2013, s. 144-157.

Schellenberg S., Perceptual Content and Relations, „Philosophical Studies” 163(1), 2013, S. $49-55$.

Schellenberg S., Perceptual Particularity, „Philosophy and Phenomenological Research” 93(1), 2016, s. 25-54. 
Sellars W., Empiricism and the Philosophy of Mind, [w:] Science,Perception and Reality, London 1963, s. 127-196.

Sellars W., Science and Metaphysics.Variations on Kantian Themes, London 1968.

Twardowski K., O treści i przedmiocie przedstawień, tłum. I. Dąbska, [w:] Wybrane pisma filozoficzne, Warszawa 1965, s. 3-91. 